\title{
ISOLASI DAN IDENTIFIKASI BAKTERI LAMUN ENHALUS ACOROIDES DI PERAIRAN PASARWAJO BUTON
}

\author{
Sabaniah Indjar Gama, Nursiah La Nafie, Seniwati Dali \\ Jurusan Kimia, Fakultas Matematika dan Ilmu Pengetahuan Alam, Universitas \\ Hasanuddin, Makassar \\ email: sndjargama@yahoo.co.id
}

\begin{abstract}
This research aims to isolation bacteria in segrass Enhalus acoroides 1) determination optimum growth factor of bacteria that symbiont in seagrass 2) identification kind of bacteria that isolated in seagrass. Base on the research that has done, the results show that bacteria symbiotically in seagrass grow in optimum temperature is $27{ }^{\circ} \mathrm{C}$ in 10-3 dilution. Identification characteristic, morphology and gram colouring bacteria that symbionts in seagrass is gram negatif bacteria that showed with result of PCR which species isolated in seagrass is enterobacter cloaceae.
\end{abstract}

Keywords: symbiont bacteria, Pasar Wajo Buton, Enhalus acoroides

\begin{abstract}
ABSTRAK
Lamun Enhalus acroides merupakan tanaman yang sangat penting bagi biota laut diperairan, salah satunya adalah bakteri karena lamun menyediakan tempat hidup serta nutrisi pada bakteri. Penelitian ini bertujuan untuk mengisolasi bakteri yang berada pada lamun Enhalus acoroides, menentukan pertumbuhan optimum bakteri yang bersimbion pada lamun dan menentukan jenis bakteri yang diisolasi pada lamun. Adapun tahapantahapan adalah isolasi, identfikasi bakteri dengan Uji fisiologis (pewarnaan), Uji Biokimia, dan PCR. Berdasarkan hasil penelitian bahwasanya bakteri yang bersimbion pada lamun Enhalus acoroides tumbuh pada suhu optimum $27^{\circ} \mathrm{C}$ pada pengenceran $10^{-3}$. Sedangkan penentuan karakter morfologi dan pewarnaan gram bakteri simbion, dilakukan berdasarkan Microbiology Laboratory Manual dan menunjukkan bahwa morfologi sel bakteri yang berada pada lamun yaitu basill (batang), hasil perwarnaan gram pada lamun diperoleh gram negatif, begitu juga uji biokimia dan diperkuat dengan data hasil polymerase chain resction (PCR) bahwa bakteri yang bersimbion pada lamun adalah Enterobacter cloacae.
\end{abstract}

Kata Kunci: bakteri simbion, Pasar Wajo Buton, Enhalus acoroides

\section{PENDAHULUAN}

Indonesia mempunyaiperairanlaut yang lebih besar dari pada daratan, oleh karena itu Indonesia dikenal sebagai Negara maritim. Perairan laut Indonesia kaya akan berbagai biota laut baik flora maupun fauna. Demikian luas dan keseragaman jasad-jasad hidup di dalam yang kesemuaannya membentuk dinamika kehidupan di laut yang saling berkesinambungan (Nybakken, 1992).
Salah satu sumber laut yang cukup potensial untuk dapat dimanfaatkan adalah lamun, dimana secara ekologis lamun mempunyai beberapa fungsi penting di daerah pesisir. Lamun merupakan produktifitas di perairan dangkal di seluruh dunia dan merupakan sumber makanan penting bagi banyak organisme (Den Hartog, 1970), selain itu juga lamun memberikan habitat bagi 
berbagai makorganisme dan mikroorganisme laut.

Salah satu factor ketertarikan organisme untuk menetap di lingkungan tersebut adalah padang lamun tergolong habitat yang produktif, sehingga mampu menyediakan makanan untuk kelangsungan hidup organisme yang berasosiasi. Selain itu sangat baik sebagai tempat berlindung dan sebagai daerah asuhan dalam siklus hidup kelompok hewan maupun tumbuhan tersebut (Tomascik et al. 1997).

Salah satu mikroorganisme yang ditemukan dalam jumlah yang melimpah ditemukan di padang lamun adalah bakteri. Bakteri merupakan komponen penting dalam proses mineralisasi pada ekosistem padang lamun. Lamun yang telah mati didekomposisi oleh bakteri, hasilnya berupa detritus sebagai makanan dari hewan-hewan laut antara lain cacing, teripang, krustase, anemon dan, ascidian, selain itu hasil degradasi organisme mati dapat menghasilkan nitrat dan fosfat yang dapat digunakan oleh tanaman lamun dan plankton. Bakteri selain berada di sekitar lamun juga berasosiasi dengan lamun, bakteri tersebut hidup pada helai daun dan cabang-cabang rimpang yang tegak. Beberapa bakteri asosiasi lamun memberikan konstribusi untuk pertahanan inangnya dengan cara mengeksresi antibiotik dan substansi bioaktif lainnya (Massinai, 2013).

\section{METODE PENELITIAN}

\section{Waktu dan tempat pengambilan sampel}

Pengambilan sampeldilakukan pada tanggal 28 Januari 2015 diperairan Pasarwajo Buton.

\section{Lokasi Penelitian}

Penelitian dilakukan di Laboratorium Biokimia Fakultas Matematika dan Ilmu Pengetahuan Alam, di Laboratorium Mikrobiologi dan Laboratorium Nehri Rumah Sakit Pendidikan Universitas Hasanuddin.

\section{Alat dan Bahan}

Alat yang digunakan adalah autoclave, cawan petri, mikropipet, ose, inkubator, neraca analitik, kain saring, tabung reaksi, erlenmeyer, beaker glass, plastik clening warp, aluminium foil.

Bahan yang digunakan adalah medium nutrien agar (NA), $\mathrm{NaCl}$ fisiologis, pewarnaan Gram digunakan larutan Safranin, Lugol Iodine, alkohol 96\% dan kristal violet, Uji biokimia menggunakan TSA, $\mathrm{H}_{2} \mathrm{~S}$, media TSI, media SIM, reagen kovac, glukosa, sukrosa, laktosa, regen metil red, medium Simmon's Citrate, Urea Broth, mediumMcConky, mediumTSIA, medium MR-VP.

\section{Persiapan sampel}

Sampel yang diperoleh dicuci bersih dengan aquades, kemudian disimpan kedalam pelastik yang berisi air laut steril dan gliserol $10 \%$.

\section{Penentuan Pengenceran}

Sebanyak 15 gram Lamun dicuci dengan air laut steril, kemudian digerus dengan penambahan $\mathrm{NaCl}$ fisiologis $0,9 \%$, setelah itu dibuat seri pengenceran dari $10^{-1}$ sampai dengan $10^{-8}$, selanjutnya dipipet sebanyak $0,05 \mathrm{~mL}$ sampel dimasukan kedalam 10-15 mL NA (metode tuang) setelah itu diinkubasi pada suhu kamar yakni suhu $27^{\circ} \mathrm{C}$.

\section{Penentuan Kondisi Optimum}

Sebanyak 15 gram Lamun dicuci dengan air laut steril, kemudian digerus dengan penambahan $\mathrm{NaCl}$ fisiologis $0,9 \%$, setelah itu dibuat seri pengenceran dari $10^{-1}$ sampai dengan $10^{-8}$, selanjutnya dipipet sebanyak $0,05 \mathrm{~mL}$ sampel dimasukan kedalam 10-15 mL NA (metode tuang) setelah itu diinkubasi pada suhu $27{ }^{\circ} \mathrm{C}, 37{ }^{\circ} \mathrm{C}$ dan $47{ }^{\circ} \mathrm{C}$ dengan waktu inkubasi $1 \times 24$ jam, $2 \times$ 24 jam, $3 \times 24$ jam, $4 \times 24$ jam dan $5 \times$ 24 jam. 


\section{Isolasi dan Identifikasi Bakteri}

Isolat bakteri dengan pengenceran yang telah ditentukan ditumbuhkan dan dimurnikan dengan metode gores. Isolat murni yang diperoleh kemudian diidentifikasi. Identifikasi yang dilakukan meliputi pewarnaan gram, pengamatan mikroskopis, pengujian biokimia (TSIA, SIM, uji fermentasi gula-gula, sitrat, urea, VP-MR) dan menentukan urutan DNA menggunakan PCR.

\section{PEMBAHASAN}

Penentuan

pengenceran, pengamatan pertumbuhan bakteri simbion lamun Enhalus acoroides dilakukan dengan cara menumbuhkan pada media nutrien agar dengan beberapa variasi pengenceran. bakteri yang bersimbion pada lamun, berada pada pengenceran $10^{-1}$ sampai dengan $10^{-3}$ yang mana mengikuti aturan perhitungan jumlah koloni bakteri dan mengikuti syarat (SPC) yakni pertumbuhan koloni tidak boleh lebih kecil dari 30 dan lebih besar dari 300 (Adriani, 2012).

Pada penelitian ini dilakukan pengamatan kondisi optimum pertumbuhan bakteri simbion pada lamun Enhalus acoroides pada suhu $27-47^{\circ} \mathrm{C}$. Kondisi optimum pertumbuhan bakteri lamun Enhalus acoroides ditumbuhkan pada media agar dengan waktu inkubasi 5 hari, untuk mengetahui pengenceran dan suhu yang baik untuk pertumbuhan bakteri.Bakteriyang bersimbion pada lamun Enhalus acoroidestumbuh pada suhu optimum $27{ }^{\circ} \mathrm{C}$ pada pengenceran $10^{-3}$.

Pertumbuhan bakteri bertambah secara teratur dan mengikuti pertumbuhan bakteri secara umum yang meliputi tahap penyesuain, pertumbuhan dan penurunan. Pada hari 1 jumlah koloni yang diperoleh sebanyak $3,8 \times 10^{-4}$, hari ke 2 jumlah koloni yang diperoleh $8,2 \times$ $10^{-4}$, hari ke 3 jumlah koloni yang diperoleh $1,42 \times 10^{-5}$, pada hari ke 4 jumlah koloni yang diperoleh $1,2 \times 10^{-4}$, pada hari ke 5 jumlah koloni yang diperoleh $1,12 \times 10^{-5}$.

Hasil identifikasi secara fisiologi diperoleh bahwa bakteri yang bersimbion pada lamun Enhalus acoroides berasal dari golongan gram negatif berbentuk batang (basill).

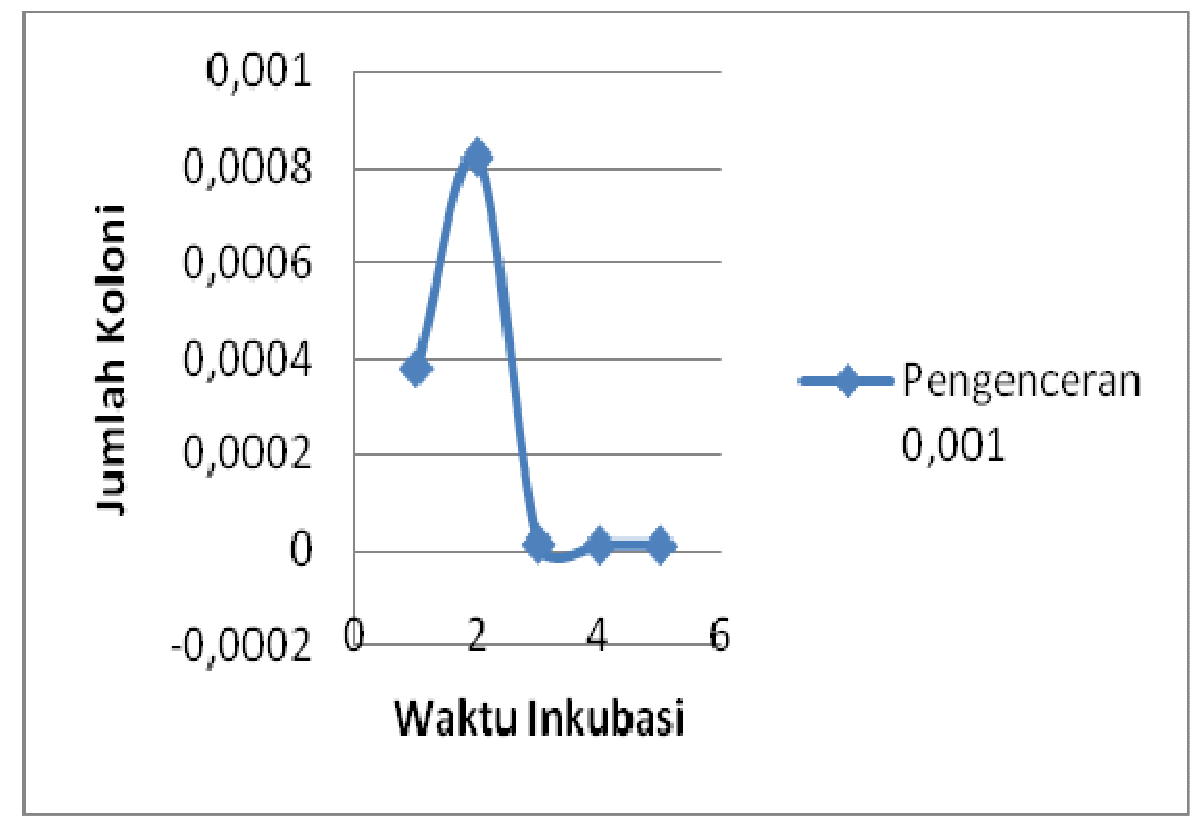

Gambar 1. Pertumbuhan koloni bakteri pada pengenceran $10^{-3}$ 


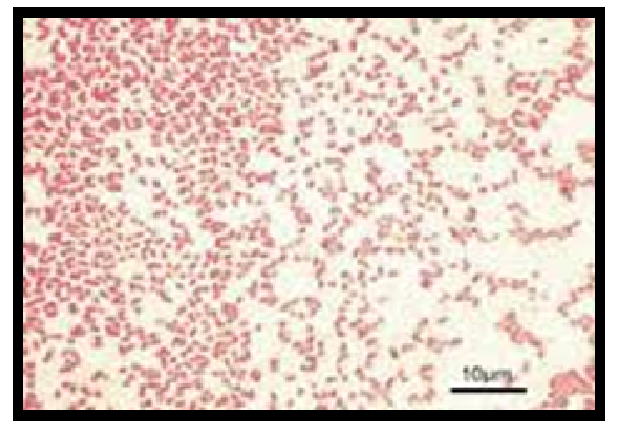

Gambar 2. Bakteri Gram negatif

Setelah diidentifikasi bakteri yang memuat ciri-ciri spesies bakteri, diketahui bahwa bakteri lamun Enhalus acoroides yang ditumbuhkan adalah Enterobacteria. Hasil uji biokimia pada bakteri lamun Enhalus acoroides yang ditumbuhkan terlihat pada Tabel 1 .

Keakuratan data yang diperoleh dari uji biokimia dan uji gram bakteri diperkuat dengan identifikasi bakteri dengan hasil PCR, yakni bakteri yang berada pada lamun Enhalus acoroides adalah bakteri Enterobactercloacae. Adapun hasil amplifikasi DNA dapat dilihat pada Tabel 2.

Proses purifikasi terlihat pada pita tunggal pada daerah 996 bp. Ini terlihat pada gambar dan susunan DNA primer 16S-RNA Entrobactercloacae terlihat pada Gambar 3.

Tabel 1. Hasil Pengujian biokimia pada bakteri lamun Enhalus acoroides yang ditumbuhkan

\begin{tabular}{ccc}
\hline \multicolumn{2}{c}{ Pengujian } & Hasil \\
\hline TSIA & Slant & Asam \\
& Buth & Asam \\
& $\mathrm{H}_{2} \mathrm{~S}$ & - \\
& Gas & + \\
\hline SIM & Indol & - \\
& Motil & + \\
& $\mathrm{H}_{2} \mathrm{~S}$ & - \\
\hline MRP & MR & + \\
& VP & + \\
\hline Sitrat & & + \\
Urea & & + \\
Glukosa & & + \\
Laktosa & & + \\
Sukrosa & & + \\
Mamitol & & + \\
\hline
\end{tabular}

Tabel 2. Amplikasi DNA

\begin{tabular}{llcc}
\hline Primer & Sekuense & Posisi amplikasi & Ukuran amplikasi \\
\hline Forward & TAATCGGATACTGGG & 962 & \\
Reverse & TAATCGGAATTACTGG & 387744 & \\
& & & $996 \mathrm{bp}$ \\
\hline
\end{tabular}




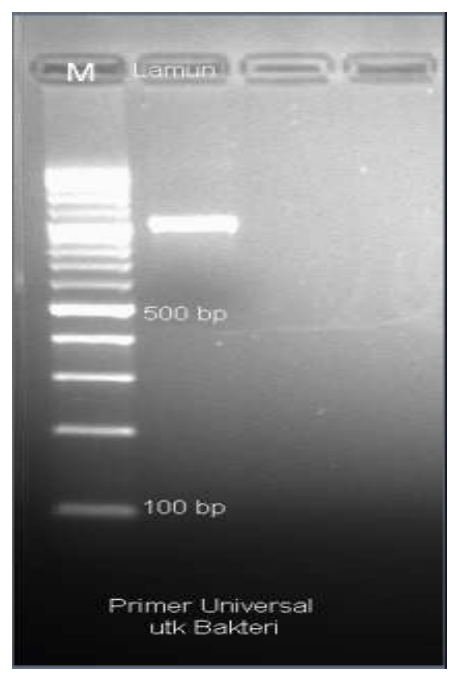

Gambar 3. Proses purifikasi terlihat pada pita tunggal pada daerah $996 \mathrm{bp}$

${ }^{386786}$ TAATCGGAATTACTGGGCGTAAAGCGCACGCAGGCGGTCTGTCAAGTCGG ATGTGAAATC 386845

${ }^{386846}$ CCCGGGCTCAACCTGGGAACTGCATTCGAAACTGGCAGGCTGGAGTCTTG TAGAGGGGGG

${ }^{386906}$ TAGAATTCCAGGTGTAGCGGTGAAATGCGTAGAGATCTGGAGGAATACCG GTGGCGAAGG ${ }^{386965}$

${ }^{386966}$ CGGCCCCCTGGACAAAGACTGACGCTCAGGTGCGAAAGCGTGGGGAGCA AACAGGATTAG ${ }^{387025}$

${ }^{387026}$ ATACCCTGGTAGTCCACGCCGTAAACGATGTCGATTTGGAGGTTGTGCCCT TGAGGCGTG ${ }^{387085}$

${ }^{387086}$ GCTTCCGGAGCTAACGCGTTAAATCGACCGCCTGGGGAGTACGGCCGCAA GGTTAAAACT ${ }^{387145}$

${ }^{387146}$ CAAATGAATTGACGGGGGCCCGCACAAGCGGTGGAGCATGTGGTTTAATT CGATGCAACG ${ }^{387205}$

${ }^{387206}$ CGAAGAACCTTACCTGGTCTTGACATCCACAGAACTTTCCAGAGATGGAT TGGTGCCTTC ${ }^{387265}$

${ }^{387266}$ GGGAACTGTGAGACAGGTGCTGCATGGCTGTCGTCAGCTCGTGTTGTGAA ATGTTGGGTT ${ }^{387325}$

${ }^{387326}$ AAGTCCCGCAACGAGCGCAACCCTTATCCTTTGTTGCCAGCGGTTAGGCC GGGAACTCAA $^{387385}$

${ }^{387386}$ AGGAGACTGCCAGTGATAAACTGGAGGAAGGTGGGGATGACGTCAAGTC ATCATGGCCCT ${ }^{387445}$

${ }^{387446}$ TACGACCAGGGCTACACACGTGCTACAATGGCGCATACAAAGAGAAGCG ACCTCGCGAGA 387505

${ }^{387506}$ GCAAGCGGACCTCATAAAGTGCGTCGTAGTCCGGATTGGAGTCTGCAACT CGACTCCATG ${ }^{387565}$

${ }^{387566}$ AAGTCGGAATCGCTAGTAATCGTAGATCAGAATGCTACGGTGAATACGTT CCCGGGCCTT $^{387625}$

${ }^{387626}$ GTACACACCGCCCGTCACACCATGGGAGTGGGTTGCAAAAGAAGTAGGTA GCTTAACCTT ${ }^{387685}$

${ }^{387686}$ CGGGAGGGCGCTTACCACTTTGTGATTCATGACTGGGGTGAAG

387743 CGTAACAAGG-TAA387742 CC 38774 


\section{KESIMPULAN}

Berdasarkan penelitian yang diperoleh bahwasanya bakteri yang diisolasi pada lamun Enhalus acoroides adalah Enterobactercloacae yang merupakan bakteri gram negatif dengan morfologi bakteri basill (batang).

\section{DAFTAR PUSTAKA}

1. Adriani, Alfian Noor, Abdul Rauf Patong, Maming. 2012. Analisis Kadar Logam $\mathrm{Cu}$ Dalam Bakteri Simbion Pada Spons Callyspongia sp. Jurnal marine acta 13 (2).

2. Brockman, F. J., Denovan, B., Hicks, R. J dan Fredicson, J. K. 1989. Isolation and characterization of quinoline degrading bacteria from subsurface sedimen. Appl. and Envinronm. Microbiology. Volume 59(1) : 340-343

3. Fenchel, T. 2001. Microorganisms (Microbes), Role of: Encyclopedia of Biodiversity 4 : 207-219.
4. Massinai, A, Abdul Haris, Eka Lisdayanti, dan Benny Audy Gosary. 2013. Lamun Pulau Bonebatang, Kepulauan Spermonde Dan Bakteri Asosiasinya, Fakultas perikanan dan kelautan Universitas Hasanuddin, Makassar.

5. Lay, B. W. 1994. Analisis mikroba di laboratorium. Jakarta: PT. Raja Grafindo Persada.

6. Ogensky, E. L. and Umbreit W. W. 1959. An inroduction to Bacterial Physiology.2nd Ed. W. H. Freman and Company, san Franscisco and London: 117134.

7. Pelczar, M. J., Chan, E. C. S. 1986. Dasar-Dasar Mikrobiologi. Jilid I. Terjemahan Ratna Siri Hadioetomo. UI Press, Jakarta.

8. Ravikumar, S., Thajuddin N., Suganthi P., Jacob S and Vinodkumar T. 2010. Bioactive Potential of seagrass bacteria against Human bacterial Pathogens. Journal of Environmental Biology. 31 (3) : $387-$ 389. 